\title{
PALAVRA DO EDITOR
}

Este é o segundo número temático da Revista do GEL, desde a sua criação em 2002. O primeiro número temático, publicado em dezembro de 2017, inaugurou um projeto de promoção e divulgação de conhecimento científico que busca articular expertises de brasileiros e estrangeiros em torno de pesquisas das áreas de Linguística e Letras. Com a publicação do presente número, o projeto vai aos poucos se consolidando e ganhando contornos mais definidos no âmbito da revista.

Sob o título "Telecolaboração transcultural e transcontinental para aprendizagem de línguas estrangeiras: propostas e desafios", as editoras convidadas Leila Martins Gonçalves da Costa (University of Miami), Ana Cristina Biondo Salomão (UNESP) e Maisa de Alcântara Zakir (UNESP) cumpriram uma grande tarefa, a de reunir trabalhos que tratam das trocas (inter)culturais, no que tange principalmente aos problemas relativos às noções de identidade e de (inter)subjetividade em situação de aprendizagem, tendo como pano de fundo o contexto de tandem, tanto nas experiências presenciais quanto nas parcerias telecolaborativas institucionais.

Contribuição inegável para os estudos sobre ensino de língua estrangeira em situação de (tele)colaboração, este número temático deixa evidente a preeminência da pesquisa brasileira na área e o papel essencial das parcerias com centros de pesquisa estrangeiros para a sua consolidação.

Assis, dezembro de 2018.

Matheus Nogueira Schwartzmann

FCL/Assis - UNESP

Editor da Revista do GEL 